\title{
Characterization of Mechanically Pretreated Wheat Straw for Biogas Production
}

\author{
Mirjam Victorin $^{1}$ (D) A Åsa Davidsson ${ }^{1}$ (D) $\cdot$ Ola Wallberg $^{1}$ (D)
}

Published online: 13 April 2020

(C) The Author(s) 2020

\begin{abstract}
Biogas production from wheat straw is one strategy of converting biomass to bioenergy, but pretreatment of the lignocellulosic material is necessary in order to render the substrate biodegradable. In this study, four different mechanical pretreatments of wheat straw were investigated: roll milling, extrusion, pelletization, and hammer milling. The effects of the pretreatments on anaerobic digestion (AD) at $37^{\circ} \mathrm{C}$ and on enzymatic hydrolysis (EH) with Cellic $\mathrm{CTec} 2$ at $50^{\circ} \mathrm{C}$ were analyzed in terms of biochemical methane potential (BMP), maximum daily methane production (DMPmax), and EH yield as amount of released glucan/initial glucan content. Roll milling generated the highest BMP of $287 \mathrm{NmL} \mathrm{CH}_{4} \mathrm{gVS}^{-1}$, an increase of $21 \%$ compared with untreated wheat straw. Extrusion provided the highest methane production rate $\left(52 \mathrm{NmL} \mathrm{CH}_{4} \mathrm{gVS}^{-1}\right.$ day $\left.^{-1}\right)$, the lowest floating capacity, and a high bulk density. It was further concluded that a linear relationship exists between the DMPmax and the EH yield $\left(R^{2}=\right.$ $0.768)$ which for roll-milled size fractioned wheat straw was even stronger $\left(R^{2}=0.900\right)$ but weaker for mechanically pretreated non-size fractioned straw $\left(R^{2}=0.625\right)$. Specific surface analysis and $\mathrm{EH}$ of $0.25-1-\mathrm{mm}$ particles revealed that mechanical pretreatment most likely affect other physiochemical properties in wheat straw, such as the crystallinity or melting of the outer wax layer, which in turn affects $\mathrm{AD}$ and $\mathrm{EH}$ processes differently.
\end{abstract}

Keywords Lignocellulose $\cdot$ BMP $\cdot$ Enzymatic hydrolysis $\cdot$ Particle size $\cdot$ SSA

\section{Introduction}

Reaching a decrease of the total greenhouse gas emissions (GHG) of $20 \%$ by year 2020, relative to 1990 levels, is one of the climate goals that the European Union has agreed upon [1], as a measure to limit the global warming to a maximal temperature increase of $2{ }^{\circ} \mathrm{C}$ compared with pre-industrial levels. Introducing biofuels, such as biogas, from renewable carbon sources is one strategy toward fulfilling these goals, and the research field around anaerobic digestion (AD) of agricultural residues and lignocellulosic biomass is consequentially growing.

Straw is one of the most abundant agricultural waste products and is rich in the biodegradable polysaccharides cellulose (ca. 35\% db.) and hemicellulose (ca. 25\% db.) [2, 3]. The polymers are, however, linked together by an anaerobically

Mirjam Victorin

mirjam.victorin@chemeng.lth.se

1 Department of Chemical Engineering, Lund University, P.O. Box 124, SE-221 00 Lund, Sweden non-degradable polyphenolic compound, lignin (ca. 10-20\% $\mathrm{db}$.), which gives the straw a rigid structure and makes it resistant to biological degradation by a number of different mechanisms such as lignin-carbohydrate bonds, physical sheathing of the cellulose and hemicellulose, as well as nonproductive adsorption of hydrolyzing enzymes [4]. Cellulose crystallinity and degree of polymerization (DP) have also been pointed out as some of the key factors for negatively affecting the degradation process [5]. Consequently, when utilizing straw as a feedstock in a biogas production process, a low methane yield and production rate is expected. This can primarily be attributed to an impeded hydrolysis, being the first reaction step in the degradation process, where the polymers are cleaved and dissolved into monomeric units through an enzymatically catalyzed reaction with water [6]. Apart from generating a low methane yield, untreated straw also poses handling issues due to its low bulk density and high tendency to form and accumulate floating layers inside the digester [7]. The floating layer is positively correlated to the dry matter (DM) content in the digester [8] and leads to a decrease in biogas production [9].

To make the carbohydrates accessible to the extracellular enzymes that are produced by the hydrolytic and fermentative 
bacteria in the digester, the structure of the straw has to be disrupted by some form of pretreatment [5]. Previous studies have investigated numerous different kinds of methods for reducing lignocellulose recalcitrance: chemical, physical, thermal, biological, and mechanical pretreatments that have been applied alone or in combination. The methods propose several strategies that aim to dissolve certain polymers while making others more accessible and/or to disrupt the physiochemical structure to thereby increase the bioaccessibility to the internal structures [5]. Although thermochemical pretreatments, such as steam explosion, have proven highly efficient in increasing the digestibility of lignocellulosic materials, they require high temperatures, added chemicals, and subsequent $\mathrm{pH}$ neutralization steps and are often designed according to one feedstock only. To avoid such measures, mechanical pretreatments can be considered.

Mechanical pretreatments mainly aim to cut, crush, grind, or press the straw into smaller pieces via chopping, milling, extrusion, pelletizing, briquetting, etc. Extrusion, for example, is based on either single or twin screw elements that by shear forces tear the material into smaller fractions while conveying it forward. Previous studies have reported that such pretreatment of lignocellulosic biomass can lead to a methane yield increase of 16 up to even $99.5 \%$ [10,11]. The reduced particle size is also believed to increase the surface area of the substrate which would have a positive effect on the methane production rate and the methane yield, assuming that the bioaccessibility to degradable substrates is simultaneously increased. There have been several studies where a positive effect of particle size reduction on the biogas or methane yield has been observed [10, 12]; however, contradicting results [13] indicate that there is discrepancy in the literature. All studies, however, show agreeing results of how the particle size reduction clearly leads to higher gas production rates, no matter the feedstock or mechanical pretreatment applied. Whether this is due to an increased specific surface area has rarely been confirmed by actual analysis.

Currently, pretreatment methods are partially evaluated based on how much the biochemical methane potential (BMP) of the concerned feedstock increases [14]. There are several proposed standard methods for determining the BMP of a material $[15,16]$, and the generated results can differ significantly both because of experimental conditions but also because of the equipment used for measurement [17]. The preparation and specific activity of the used inoculum also affects the methane production kinetics and the methane yield [18] which makes the comparability between different studies even more complicated [14]. In addition, the assay is very time-consuming (30-90 days) and lengthens the optimization process of a pretreatment method.

As a result of this prevailing issue, many researchers have made efforts to model and conclude the dominant characteristics of lignocellulosic biomass that affect the AD process.
Being able to describe these characteristics can serve dual purposes as it both opens up the possibility for creating time efficient simulation tools that may predict the performance of a feedstock and/or a pretreatment method, as well as increases the understanding for how properties correlate and what function they serve. It has been repeatedly shown that the most important factor for BMP predictions is the lignin content of the feedstock $[19,20]$ and that the accuracy can be improved if both degradable and non-degradable compounds are included as independent variables, i.e., polysaccharides/lignin ratio [19, 21]. Further physiochemical properties such as accessible specific surface area, crystallinity, pore size, and degree of polymerization have also been mentioned as important factors for the digestibility of the biomass [5]. However, the intricacy of the lignocellulosic matrix and the heterogeneity in physiochemical composition both between and within herbaceous species makes it very hard to isolate and study these properties. If the aim is also to create a time efficient model for BMP predictions, it seems unwise to include too many factors that require time-demanding analysis.

Interestingly, fungal cellulases that are predominantly used in commercial holocellulose degrading enzyme mixtures are, although not identical to the active hydrolytic enzymes and bacteria in anaerobic digestion processes, reportedly affected by similar physiochemical properties [6] Studies have been conducted on whether enzymatic hydrolysis $(\mathrm{EH})$ can be utilized as a predicting method for the BMP of lignocelluloses, since enzymatic digestibility of lignocelluloses also primarily depends on the lignin content, which has been shown by collecting different plant species [21] or by adjusting the lignin content through applying severe pretreatment [22]. The glucose production following EH did not, however, seem to be a suitable predictive parameter for the BMP of mechanically pretreated grass silage, as seen in a study by Tsapekos et al. [20]. In contrast, a number of studies have shown a positive linear correlation between the aforementioned parameters generated from arrays of different plant species [22] and from application of mechanical pretreatment [23]. Furthermore, when alkali pretreatment on wheat straw was optimized by Liu et al. [3], similar increasing trends were observed in methane yield as well as enzymatic hydrolysis when increasing the pretreatment severity, although no model was proposed in that study [21]. Wahid et al. [24] showed how the sugar availability, measured via enzymatic hydrolysis, was linearly correlated to the methane yield after 28 days of digestion, of extruded wheat straw, and of extruded deep litter. It was argued that the methane yield after 28 days was a reflection of the rate of methane production, as the maximum BMP had not yet been reached. As previously mentioned, mechanical pretreatment of lignocellulosic biomass largely affects the particle size. Assuming the particle size reduction also increases the surface area 
of the material, the kinetics of the hydrolysis step should improve as this is often regarded as the rate limiting step.

In this work, we aimed to test four different mechanical pretreatments on wheat straw and to analyze the effect they have on anaerobic digestion as well as enzymatic hydrolysis to determine whether enzymatic hydrolysis could be utilized as a quick characterization method and replace BMP tests. A linear correlation between maximum daily methane production and the glucose yield is presented, enabling faster evaluations of the performance of a mechanical pretreatment on the anaerobic digestion of wheat straw. Additional assessments of the floating layer formation capacity and of the effect of particle size reduction on both $\mathrm{AD}$ and $\mathrm{EH}$ were also done.

\section{Materials and Methods}

\section{Collection of Sample}

Winter wheat straw was harvested in Denmark and was fed into a chopper which cut the straw into $5-10 \mathrm{~cm}$ pieces. The straw was then transported to the laboratory where it was airdried to a moisture content below $10 \%$ and stored in air-tight buckets at room temperature $\left(21^{\circ} \mathrm{C}\right)$ until further use.

\section{Mechanical Pretreatment}

The chopped wheat straw was used for four different mechanical pretreatments: roll milling, extrusion, hammer milling, and palletization. The roll milling was performed with a specially designed roll mill (TK Energi, Køge, Denmark) described in Hansen et al. [25]. The extrusion was carried out with a twin-screw extruder (Extruder MSZK 15, LEHMANN Maschinenbau, Jocketa, DE) at a rotation speed of $17 \mathrm{~min}^{-1}$, equipped with counter-rotating screw modules that consisted of a conveying element followed by a compression element and finally a reverse screw element, and with a fully opened adjustable outlet. Pelletization of the wheat straw was performed by the Biomass Technology Centre at the Swedish University of Agricultural Science (Umeå, Sweden) to a durability of $93 \%$. Hammer milling was done with a hammer mill (Retsch Cross Beater Hammer Mill Sk1, Retsch, Haan, Germany) equipped with a $1 \mathrm{~mm}$ mesh.

\section{Bulk Density and Floating Layer Formation}

The bulk density of the wheat straw was determined by recording the volume of $100 \mathrm{~g}$ of material in a glass beaker. To assess the floating layer formation capacity of the material, $100 \mathrm{~g}$ of wheat straw was put into a $1000-\mathrm{mL}$ glass measuring cylinder whereby water was added in $200-\mathrm{mL}$ portions, up to a total volume of $1000 \mathrm{~mL}$. After each addition, the straw-water slurry was mixed, and the volume of the floating layer $\left(V_{F}\right)$ as well as the sediment layer $\left(\mathrm{V}_{\mathrm{S}}\right)$ was recorded together with the total weight. The floating index $\left(\mathrm{I}_{\mathrm{F}}\right)$ was calculated as described in Eq. 1.

$I_{F}=\frac{V_{F}}{\left(V_{F}+V_{S}\right)}$

\section{Particle Size Fractionation}

Roll-milled wheat straw was sieved with a vibratory sieve shaker (Sieve shaker AS 200 basic, Retsch, Haan, Germany) with multiple meshes of appropriate sizes, at an amplitude of $30 \%$ $(0.9 \mathrm{~mm})$ for $10 \mathrm{~min}$. Depending on the mesh size of the stacked sieves, different size fractions of wheat straw were obtained. The following two arrays were created: [4-8 mm, 2-4 mm, 1-2 mm, $0.25-1 \mathrm{~mm}$, and $<0.25 \mathrm{~mm}]$ and [6-8 $\mathrm{mm}, 5-6 \mathrm{~mm}, 4-5 \mathrm{~mm}$, 3-4 mm, 2-3 mm, 1-2 mm, 0.25-1 mm, and $<0.25 \mathrm{~mm}$. The latter sieve array was done in order to improve the resolution of the size fractionation and was also then used for determination of the particle size distribution (w/w) of the untreated, roll-milled, extruded, pelletized, and hammer-milled straw. The average of a size fraction was calculated as the average between the upper and the lower limit of the interval. The mean particle size $\overline{P S}$ of the mechanically pretreated straw was defined as the weighted arithmetic mean of the averages $P S_{i}$ of all size fractions, seen in Eq. 2.

$\overline{P S}=\sum_{i=1}^{8} P S_{i} \cdot \frac{m_{P S_{i}} \ddot{A}}{m}$

$m_{P S_{i}}$ is the weight of the size fraction $i$, the number of which signifies the position of the size fraction in the sieve array, and $m$ is the total mass of the sample that has been sieved.

\section{Biochemical Methane Potential (BMP) Tests}

For measurement of the BMP value, an Automatic Methane Potential Test system (AMPTS II, Bioprocess engineering, Lund, Sweden) was used with integrated carbon dioxide traps ( $3 \mathrm{M} \mathrm{NaOH})$, whereby data of the normal volumetric daily methane production was obtained $\left(0{ }^{\circ} \mathrm{C}, 1 \mathrm{~atm}\right)$. Sludge from a digester at a wastewater treatment plant treating municipal waste was harvested and degassed for $3-4$ days at $37^{\circ} \mathrm{C}$ to be used as inoculum, after which the BMP test was set up in 500-mL bottles, with a total liquid volume of $300 \mathrm{~mL}$ and a total volatile solids (VS) load of $3 \mathrm{~g} \mathrm{VS} / 100 \mathrm{~mL}$ liquid. Straw samples were added at an S/I ratio of 1:2 (g VS straw/g VS inoculum) in accordance with Hansen et al. [15]. To create an anaerobic environment, the bottles were flushed with pure nitrogen gas. The test was run at mesophilic conditions $\left(37^{\circ} \mathrm{C}\right)$ with continuous stirring at $150 \mathrm{rpm}$, until the gas production stopped after 35 days. After termination, the $\mathrm{pH}$ was measured with a $\mathrm{pH}$ meter (WTW pH 320, Christian Berner AB, Partille, Sweden) to check for potential $\mathrm{pH}$ drops that could have had an effect on methanogenic activity. The technical digestion time (T80), i.e., the number of 
days it takes for the methane yield to reach $80 \%$ of the final BMP value, was also calculated as an indicator for the methane productivity.

\section{Enzymatic Hydrolysis}

Enzymatic hydrolysis of wheat straw was carried out with Cellic Ctec2 (Novozymes, Denmark), which had an activity of $235 \pm 4$ FPU/g, in 500-mL glass bottles, with a total reaction volume of $400 \mathrm{~mL}$. The temperature was set to $50{ }^{\circ} \mathrm{C}$, and $0.1 \mathrm{M}$ sodium acetate buffer was used to keep the $\mathrm{pH}$ at 5-5.5, as recommended by the manufacturer, which was controlled with a pH meter (HI$8424 \mathrm{pH}$ Meter, HANNA Instruments, Bedfordshire, UK). Wheat straw was added until $2 \%$ TS, which enabled mixing. To avoid the risk of infection, a penicillin-streptomycin solution of $10 \mathrm{~mL} / \mathrm{L}$ was used (Penicillin-Streptomycin P4333, SigmaAldrich, Darmstadt, Germany). The enzymatic hydrolysis yield (EH yield) was calculated according to Eq. 3 [26].

EH yield $(\%)=100 \cdot \frac{c_{\text {glucose }} \cdot V \cdot 0.9}{X_{\text {glucan }} \cdot O D W_{\text {straw }}}$

Where the $c_{\text {glucose }}$ is the monomeric glucose concentration $(\mathrm{g} / \mathrm{L})$ in the reaction liquid, $V$ is the liquid reaction volume $(\mathrm{L})$ which is assumed to be constant, $X_{\text {glucan }}$ is the glucan content in the wheat straw $(\% \mathrm{DM})$, and the $O D W_{\text {straw }}$ is the oven dry weight $(\mathrm{g})$ of the wheat straw. The EH yield is given as $\mathrm{g}$ glucan/100 g initial glucan, which is why it has been multiplied by the anhydro correction factor of 0.9 . For simplicity, the $E H$ yield is further on expressed as \% glucan.

The enzymatic hydrolysis of roll-milled wheat straw was tested at different enzyme loads to assess at which enzyme load that the hydrolysis was primarily limited by the substrate characteristics. It was then further on performed on a set of samples expected to show different EH yields-roll-milled size fractioned straw - to investigate if the analysis time could be shortened from 96 to $24 \mathrm{~h}$, which it could. To be able to increase the number of samples that can be run simultaneously, the $\mathrm{EH}$ was downscaled to $100 \mathrm{~mL}$ total liquid volume, run in $120 \mathrm{~mL}$ glass serum bottles, kept airtight with a rubber cap and an aluminum seal. As the experiment time had already been set to $24 \mathrm{~h}$, sampling was only done twice: at the start and finish of the experiment, avoiding loss of sample during the experiment. An incubator (IKA® KS 4000 ic control, IKA®Werke GmbH \& CO.KG, Staufen, Germany) with a shaker set to $200 \mathrm{rpm}$ was used to heat and mix the slurry.

\section{Analytical Methods}

\section{Chemical Composition}

All pretreated and size fractioned straw samples as well as the inoculum were analyzed for TS and VS contents, following
NREL (National Renewable Energy Laboratory, Golden, Colorado, USA) standard procedures [27, 28]. The water and ethanol extractives content in dry roll-milled wheat straw was determined according to NREL standard method [29], followed by structural carbohydrate and lignin content analysis [30].

\section{Monomeric Sugar Analysis}

Monomeric sugars were measured using high-performance anion-exchange chromatography coupled with pulsed amperometric detection (ICS-3000, Dionex Corp., Sunnyvale, CA, USA), with a Carbo Pac PA1 analytical column. The sample injection volume was $10 \mu \mathrm{L}$, and deionized water was used as an eluent at a flowrate of $1 \mathrm{~mL} / \mathrm{min}$, prior to cleaning the column with $200 \mathrm{mM} \mathrm{NaOH}$ in $170 \mathrm{mM}$ sodium acetate at a flowrate of $0.5 \mathrm{~mL} / \mathrm{min}$. The glucan and xylan contents were calculated based on the glucose and xylose contents, after anhydro corrections of 0.88 and 0.90 , respectively.

\section{Specific Surface Area Analysis}

The specific surface area (SSA) was measured with a Micromeritics 3Flex BET-analyzer (Micromeritics Instrument Corp., Norcross, USA) where $1-2 \mathrm{~g}$ dry wheat straw was degassed for $38 \mathrm{~h}$ at $40{ }^{\circ} \mathrm{C}$ and then for $38 \mathrm{~h}$ at $90{ }^{\circ} \mathrm{C}$, prior to krypton gas adsorption [31] at $77 \mathrm{~K}$ using porous isothermal jackets. The relative pressure ranged from 0.05 to $0.30 \mathrm{P} / \mathrm{P}_{0}$. Using the Brunauer-Emmett-Teller (BET) theory [32], the SSA could be calculated.

\section{Statistical Methods}

The BMP values as well as the EH yields were analyzed for statistically significant differences via one-way ANOVA, with subsequent Student's two-tailed $t$ test $(p<0.05)$. A linear regression model with the least square method was constructed to investigate possible linear correlation between the DMPmax (dependent variable) and the EH yield (independent variable). The model was assessed with a lack of fit $F$ test.

\section{Results and Discussion}

The chemical composition of the wheat straw used throughout this study is presented in Table 1. The compositional values are typical for wheat straw characterized according to the same method. Based on the carbohydrate content and assuming a protein content of $4 \%$ TS and a lipids content of $2 \%$ TS $[10,33]$, the theoretical maximal BMP of this wheat straw can be estimated to approximately $308 \mathrm{NmL} / \mathrm{g}$ VS. This can be calculated by applying the formula created by Buswell and Hatfield [34] and assuming that carbohydrates, proteins, and 
Table 1 The chemical composition of wheat straw given as percentage of the total solids content (TS) in the material. The error represents the sample standard deviation of triplicates

\begin{tabular}{ll}
\hline Compound $(\% \mathrm{TS})$ & Wheat straw \\
\hline Volatile solids & $95.0 \pm 0.2$ \\
Ash & $5.0 \pm 0.2$ \\
Extractives & $12.2 \pm 0.6$ \\
Glucan & $35.1 \pm 2.2$ \\
Xylan & $20.1 \pm 1.1$ \\
Arabinan & $2.6 \pm 0.2$ \\
Mannan & $2.3 \pm 0.2$ \\
Galactan & $1.0 \pm 0.1$ \\
Lignin & $16.3 \pm 1$ \\
\hline
\end{tabular}

lipids follow the chemical formulas of $\mathrm{C}_{6} \mathrm{H}_{10} \mathrm{O}_{5}, \mathrm{C}_{5} \mathrm{H}_{7} \mathrm{O}_{2} \mathrm{~N}$, and $\mathrm{C}_{57} \mathrm{H}_{104} \mathrm{O}_{6}$, respectively [35]. Lignin was regarded as a non-degradable compound and was thus not included in the calculation of the theoretical maximal BMP.

\section{Method Development of Enzymatic Hydrolysis of Wheat Straw}

The enzymatic hydrolysis of roll-milled wheat straw, performed as $400-\mathrm{mL}$ batch experiments, was tested at different enzyme loads (a) to assess at which enzyme load that the hydrolysis was primarily limited by the substrate characteristics and further on performed on size fractioned straw (b) to investigate if the analysis time could be shortened from 96 to $24 \mathrm{~h}$. The results are shown in Fig. 1.

An increased enzyme load (Fig. 1a) led to a clear increase in EH yield, although the effect was less prominent for comparisons between higher dosages, following the Langmuir-type equation described in Sattler et al. [36]. At higher enzyme dosages, the hydrolysis yield is most likely low due to the recalcitrance of the wheat straw and its impact on the initial hydrolysis rate and not due to a

a)

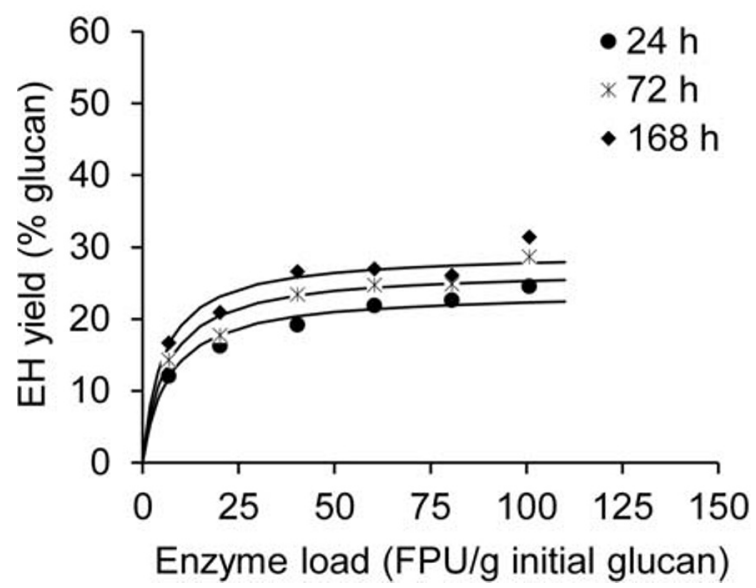

lack of enzymes. Further analysis on size fractioned wheat straw was therefore run at $100 \mathrm{FPU} / \mathrm{g}$ glucan. Because of the high enzyme dosage, the initial hydrolysis rate became very high, and as a consequence, the $\mathrm{EH}$ yield did not increase much after $24 \mathrm{~h}$. Accordingly, the analysis time was set to $24 \mathrm{~h}$.

To investigate the possibility of decreasing the reaction volume and thereby increase the number of samples that could be run simultaneously, the experiment was repeated in $120-\mathrm{mL}$ bottles with a reaction volume of $100 \mathrm{~mL}$. Figure 2 shows the resulting EH yield as a function of enzyme load (Fig. 2a) and particle size (Fig. 2b). An enzyme loading of $100 \mathrm{FPU} / \mathrm{g}$ glucan was used on size fraction roll-milled wheat straw (Fig. 2b) after first testing a range of different enzyme loadings (Fig. 2a) and choosing the concentration at which the EH yield increased by the same rate as in previous analysis.

As expected, the EH yield increased with an increasing enzyme load. The same enzyme load (100 FPU/g glucan) was chosen for EH on roll-milled size fractioned wheat straw, as an enzyme load higher than this did not generate a noticeably higher EH yield. However, the difference between the size fractioned samples was less prominent as compared with when the analysis was run in larger flasks.

\section{The Effect of Mechanical Pretreatment on Anaerobic Digestion}

Figure 3 shows the methane yield and the daily methane production (DMP) obtained from the BMP test run on mechanically pretreated wheat straw. The BMP test showed that mechanically pretreated wheat straw generates methane yields within the range of 240-290 NmL/g VS, see Table 2, which are common values for lignocellulosic biomass [19] and corresponds to $78-94 \%$ of the previously estimated theoretical

b)

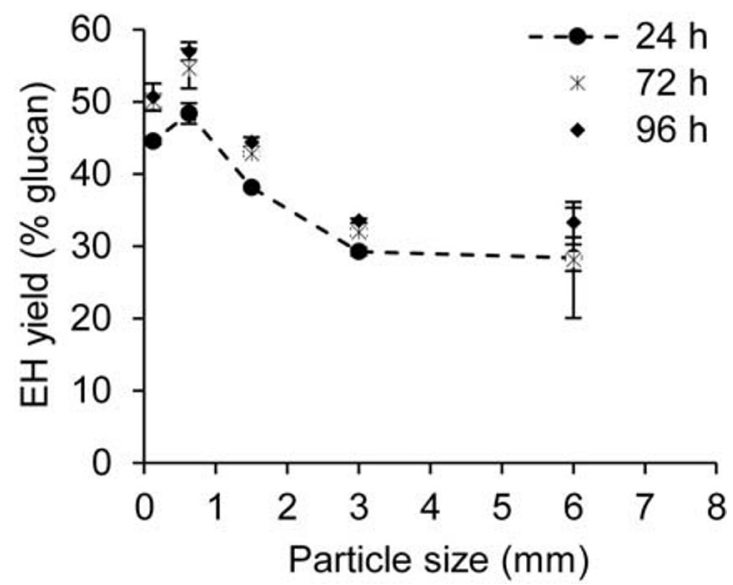

Fig. 1 The enzymatic hydrolysis yield after EH of a roll-milled wheat straw at different enzyme loadings and b roll-milled size fractioned wheat straw. The error bars represent the sample standard deviation of triplicates 


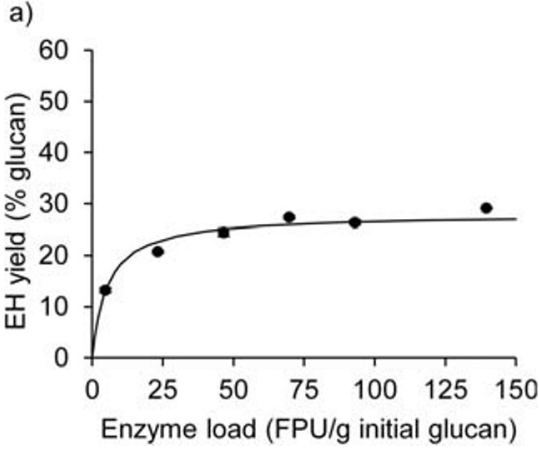

Fig. 2 The enzymatic hydrolysis of roll-milled wheat straw, performed as $100 \mathrm{~mL}$ batch experiments, was tested at different enzyme loads a to assess at which enzyme load that the hydrolysis was primarily limited by the substrate characteristics after $24 \mathrm{~h}$, and further on performed on

maximal BMP. Most of the gas was produced during the first 10-15 days, after which the production rate markedly decreased. The mechanical pretreatment of the wheat straw led to a slight improvement in methane yield $(+0-21 \%)$, as well as maximum daily methane production $(+0-27 \%)$. The technical digestion time was only improved for the extruded and the pelletized wheat straw, with a decrease of 46 and $38 \%$, respectively. All samples had a final $\mathrm{pH}$ of ca. 7, whereby the possibility that the methane production process ceased due to inhibition via VFA accumulation was rejected.

Roll-milled straw generated the highest BMP value of 287 \pm 24 which was significantly higher $(p=0.039)$ than the BMP of untreated straw, $237 \pm 16 \mathrm{NmL} / \mathrm{g}$ VS. However, no such amelioration was seen in regard to the maximum daily methane production, which was surprisingly also the case for the hammer-milled wheat straw. The extruded wheat straw, on the other hand, showed a $28 \%$ increase in DMPmax, compared with untreated straw. Interestingly, the BMP was not significantly enhanced $(p=0.984)$.

Extrusion of cereal straw has in some cases been reported to have a positive effect on the methane yield [11]. Hjorth et al. [37] concluded that the extrusion increases the degradation b)

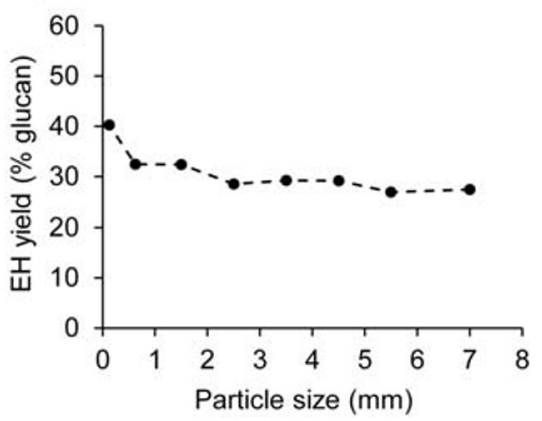

size fractioned straw $\mathbf{b}$ to investigate if the results would be coherent with the $400-\mathrm{mL}$ experiments. The error bars represent the sample standard deviation of triplicates

efficiency, which was reflected by a $70 \%$ increase in methane yield after 28 days of digestion of extruded barley straw, but does not render non-degradable compounds susceptible to biological conversion since the methane yield increase became insignificant after 110 days of digestion. Similar observations were presented by Perez-Rodríguez et al. [38] where the difference in methane yield between untreated and extruded corn cobs was noticeably higher in the beginning of the digestion period but appeared to diminish after 32 days. Wahid et al. [24] reported a $14-28 \%$ and a $1-16 \%$ methane yield increase from extrusion of wheat straw, after 28 and 90 days of digestion, respectively, which further lends support to the aforementioned claim by Hjorth et al. [37]. These studies suggest that extrusion affects the methane production rate, alas the technical digestion time, and not the final yield, which agrees with the observed results in this study. Pelletization of wheat straw showed a very similar effect as extrusion on the anaerobic digestion, in contrast to Mönch-Tegeder et al. [7] who reported a higher final methane yield from pelletized straw $(247 \mathrm{NmL} / \mathrm{g} \mathrm{VS})$ than non-pelletized straw. However, the biomass in that study did not come from the same original source which com-
Fig. 3 The cumulative methane production (left) and the daily methane production (right) of mechanically pretreated wheat straw

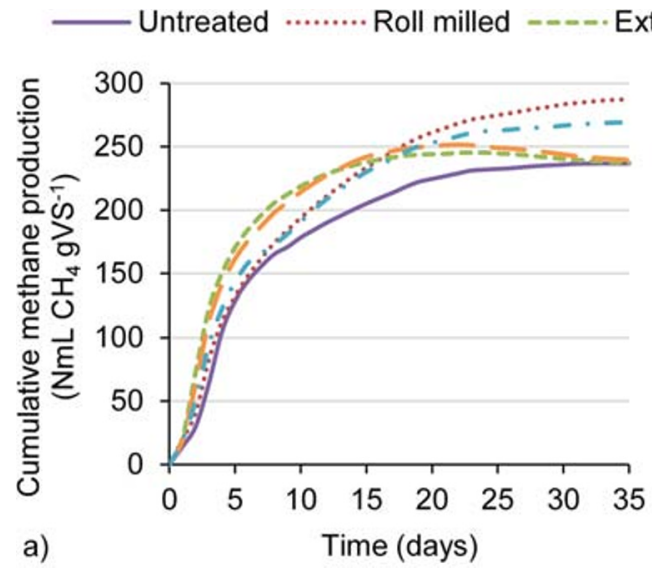

Extruded - - Pelletized - - - Hammer milled

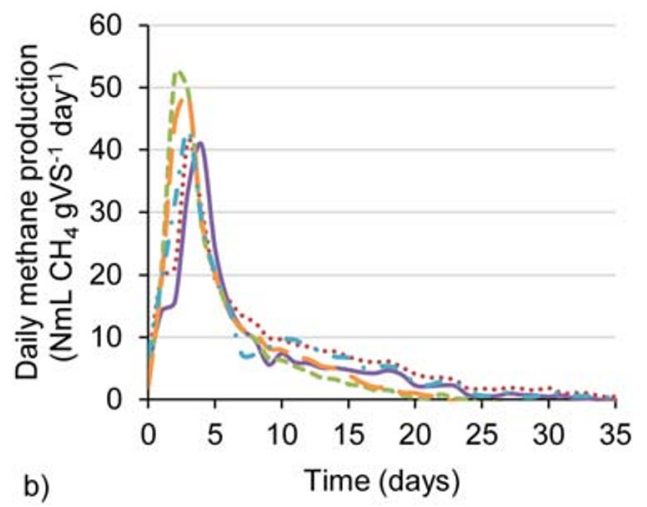


Table 2 The biochemical methane production (BMP), the maximum daily methane production (DMPmax), the technical digestion time (T80), and the enzymatic hydrolysis yield (EH yield) of pretreated wheat straw

\begin{tabular}{lllll}
\hline Pretreatment & $\begin{array}{l}\mathrm{BMP} \\
\left(\mathrm{NmL} \mathrm{CH} \mathrm{g} \mathrm{VS}^{-1}\right)\end{array}$ & $\begin{array}{l}\mathrm{DMP}_{\max } \\
\left(\mathrm{NmL} \mathrm{CH}_{4} \mathrm{~g} \mathrm{VS}^{-1} \text { day }^{-1}\right)\end{array}$ & $\begin{array}{l}\mathrm{T} 80 \\
(\text { days })\end{array}$ & $\begin{array}{l}\text { EH yield } \\
\text { (\% glucan) }\end{array}$ \\
\hline Untreated & $237 \pm 16^{\mathrm{a}}$ & $41 \pm 5$ & $12 \pm 4$ & $34 \pm 0.0^{\mathrm{a}}$ \\
Roll milled & $287 \pm 24^{\mathrm{b}}$ & $41 \pm 4$ & $14 \pm 1$ & $34 \pm 0.2^{\mathrm{a}}$ \\
Extruded & $237 \pm 26^{\mathrm{abc}}$ & $52 \pm 2$ & $6 \pm 1$ & $45 \pm 1.1^{\mathrm{b}}$ \\
Pelletized & $239 \pm 4^{\mathrm{ac}}$ & $49 \pm 0$ & $7 \pm 1$ & $43 \pm 2.2^{\mathrm{b}}$ \\
Hammer milled & $269 \pm 10^{\mathrm{bc}}$ & $43 \pm 1$ & $13 \pm 2$ & $41 \pm 1.1^{\mathrm{b}}$ \\
\hline
\end{tabular}

The errors represent the sample standard deviation. Numbers appearing in the same columns, followed by the same letters, are not statistically different, determined via Student's $t$ test $(p<0.05)$ plicates the comparison. No other studies were found on anaerobic digestion of pelletized straw.

\section{The Effect of Mechanical Pretreatment on Enzymatic Hydrolysis}

The untreated and roll-milled straw showed no significant difference in terms of $\mathrm{EH}$ yield, reaching a value of $34 \%$ glucan after $24 \mathrm{~h}$, see Table 2 where numerical results from the BMP test of mechanically pretreated wheat straw are also shown in the table to enable comparisons between the processes. However, all other pretreatments showed a significantly higher EH yield $(p=0.050)$ than the untreated straw and the roll-milled straw with extrusion leading to a $32 \%$ improvement with a yield of $45 \%$ glucan, which is still a low yield compared with thermochemical pretreatments that can lead to EH yields of 80-90\% [39]. The EH yield after $24 \mathrm{~h}$ of EH was primarily determined by the initial reaction rate, here defined as the first $4 \mathrm{~h}$, which can be associated with physiochemical properties such as specific surface area, enzyme adsorption [40], and cellulose crystallinity [41]. No significant difference was observed between the extruded, knife milled, and the pelletized straw. As the enzyme load was very high, it is not likely that the observed significant improvement derived from a difference in enzyme adsorption rate but rather from a change in the structure of the mechanically pretreated straw.

\section{Characterization of Physical Properties of Mechanically Pretreated Straw}

The mechanically pretreated wheat straw was characterized by measuring physical properties such as the bulk density, the floating index $\left(I_{F}\right)$, and the particle size distribution as well as a mean particle size (mean PS). Furthermore, the specific surface area (SSA) of 0.25-1mm-size fractions from all pretreatments was determined in order to investigate whether it could be linked to any differences in digestibility or estimated via enzymatic hydrolysis. The results are presented in Table 3 .

\section{Floating Layer Formation and Bulk Density}

Not surprisingly, the untreated and roll-milled straw had both very low bulk densities and did not sediment notably when introduced into water. Interestingly, the density of the extruded straw exceeded that of the knife milled straw with a factor two, even though the mean particle size of both materials was similar (Table 3). This may be due to that the extruded straw particles were shorter than the knife milled ones thus allowing a more dense packing and that extrusion might have a higher effect on releasing air from the straw structure. However, the floating layer formation tests revealed that a higher bulk density does not necessarily lead to a lower floating index, $\mathrm{I}_{\mathrm{F}}$. The pelletized straw, which had the highest density of $652 \mathrm{~kg} / \mathrm{m}^{3}$, resulted in an $\mathrm{I}_{\mathrm{F}}$ of 0.29 in contrast to the extruded straw which measured a density twice as low $\left(334 \mathrm{~kg} / \mathrm{m}^{3}\right)$ but with an $\mathrm{I}_{\mathrm{F}}$ of 0.04 . Most likely, the density distribution is broader in the pelletized straw, with some particles of a higher density and some particles $(29 \% \mathrm{v} / \mathrm{v})$ of a lower density than water $\left(997 \mathrm{~kg} / \mathrm{m}^{3}\right.$ at STP) that rise to the surface when the pellets disintegrate in water. Since $\mathrm{I}_{\mathrm{F}}$ is a volumetric index, it does not take the difference in density of the floating and sediment layers into account and can therefore not indicate how much biomass that might be unavailable for anaerobic digestion.

As the wheat straw contained $12 \%$ extractives, it is probable that the wax content was high enough to render the external surface hydrophobic, which means that the wettability of the straw would be low [42], and thus its capacity to absorb water. However, severe pretreatment may alter the surface morphology of lignocellulosic biomass and expose more hydrophilic groups which might contribute to a higher wettability. It is possible that mechanical pretreatment processes with higher energy inputs in combination with longer retention times, such as pelletization and extrusion, are more efficient 
Table 3 The physical properties of the mechanically pretreated wheat straw

\begin{tabular}{llllll}
\hline Pretreatment & $\begin{array}{l}\text { Bulk density } \\
\left(\mathrm{kg} / \mathrm{m}^{3}\right)\end{array}$ & $\begin{array}{l}\mathrm{I}_{\mathrm{F}} \\
\left(\mathrm{V}_{\mathrm{f} 1 \mathrm{o} \mathrm{a}} /\right.\end{array}$ & $\begin{array}{l}\text { Mean PS } \\
(\mathrm{mm})\end{array}$ & $\begin{array}{l}\text { SSA } \\
\left(\mathrm{m}^{2} /\right. \\
\mathrm{g})\end{array}$ & $\begin{array}{l}\text { EH yield } \\
(\% \text { glucan })\end{array}$ \\
\hline Untreated & 33 & 1.00 & $3.1 \pm 0.3$ & 0.082 & $33 \pm 0.7^{\mathrm{a}}$ \\
Roll milled & 91 & 1.00 & $3.0 \pm 0.2$ & 0.072 & $35 \pm 0.2^{\mathrm{a}}$ \\
Extruded & 334 & 0.04 & $0.7 \pm 0.1$ & 0.088 & $44 \pm 0.1^{\mathrm{b}}$ \\
Pelletized & 652 & 0.29 & $1.2 \pm 0.0$ & 0.100 & $37 \pm 0.2^{\mathrm{c}}$ \\
Hammer milled & 152 & 0.91 & $0.6 \pm 0.1$ & 0.114 & $39 \pm 0.3^{\mathrm{d}}$ \\
\hline
\end{tabular}

The errors represent the sample standard deviation. Numbers appearing in the same columns, followed by the same letters, are not statistically different, determined via Student's $t$ test $(p<0.05)$ in reducing the floating layer formation tendency as a consequence of altering the hydrophobicity of the wheat straw surface.

Although the $\mathrm{I}_{\mathrm{F}}$ alone might not affect the final BMP in batch experiments, it may have an impact on the methane production rate and alas the technical digestion time due to the reduced bioaccessibility to the substrate as a consequence of a lower wetted contact surface area toward the microorganisms. In our study, when ranking the floating layer formation tendency of the pretreated straw from high to low (Untreated $=$ Roll milled $>$ Knife milled $>$ Pelletized $>$ Extruded), it follows the inverse trend as the maximum daily methane production (Extruded $>$ Pelletized $>$ Knife milled $>$ Roll milled $=$ Untreated). Unfortunately, the floating layer formation could not be studied during the anaerobic digestion process, due to the relatively low substrate load that did not take up enough volume to form a consistent floating layer, as well as impaired visibility by the black colored inoculum. Any affect that the floating capacity of the straw had on the maximum daily methane production during the BMP tests would thus not be because of a physical barrier trapping the biogas underneath but because of limited bioaccessibility.

\section{Specific Surface Area Analysis and Enzymatic Digestibility of Mechanically Pretreated Straw}

BET analysis of untreated, roll-milled, extruded, pelletized, and knife-milled wheat straw samples that were sieved to a size fraction of $0.25-1 \mathrm{~mm}$ showed that the total specific surface areas (Table 3) were around $0.1 \mathrm{~m}^{2} / \mathrm{g}$ for all samples; knife milling measuring the highest SSA of $0.11 \mathrm{~m}^{2} / \mathrm{g}$ and the roll-milled straw the lowest SSA of $0.07 \mathrm{~m}^{2} / \mathrm{g}$. The difference in SSA between the extruded, knife-milled, and pelletized straw samples $\left(0.088,0.100\right.$, and $0.114 \mathrm{~m}^{2} / \mathrm{g}$, respectively) might be a result of probable differences in particle size distribution within the $0.25-1-\mathrm{mm}$-size fraction, sphericity of the straw particles, or their cell wall surface morphology. The outer wax layer on straw may also affect the measurement as the krypton gas cannot penetrate those structures and is therefore unable to cover any inner pores that might be situated underneath [43].

The change in SSA did not correlate to the EH yield obtained after enzymatic hydrolysis as the extruded straw in this case generated a higher yield than the other pretreatments despite the lower SSA. A difference in enzymatic digestibility can therefore not solely be explained by any measureable changes in the specific surface area. As both hydrolytic fungal enzymes (Cellic CTec2) and bacterial enzyme complexes (e.g., cellulosomes) are much larger than krypton gas molecules (4-5 $\mathrm{nm}$ and $18 \mathrm{~nm}$ [44 46] vs $0.52 \mathrm{~nm}$ in diameter, respectively), the specific surface area will always exceed the bioavailable surface area [43] of lignocellulosic materials measured with this method. Since BET analysis is performed under dry conditions, no information can be obtained about the surface area of the particles in liquid, which can be significantly different as the interactions with water may cause swelling of the fibers.

Regarding the effect that a change in SSA might have on the methane yield and methane production rate, it is likely that the observed surface area differences in this study are too small and thus insignificant for both AD and EH. Josef Marousek [47] showed in his study that the micropore SSA (i.e., area made up of pores with a diameter lower than $2 \mathrm{~nm}$ ) of wheat straw seemed to correlate nonlinearly to the methane yield after steam explosion or pressure shockwaves pretreatment (SSA $\left.>20 \mathrm{~m}^{2} / \mathrm{g}\right)$. However, no such trend was observed after hot maceration ( $\mathrm{SSA}<12 \mathrm{~m}^{2} / \mathrm{g}$ ). The micropore specific surface area could not be determined in this study, as krypton gas is not suitable for the higher pressures applied during multimolecular layer measurements.

It is still possible that other changes in the lignocellulosic structure, e.g., the crystallinity, have occurred affecting the bioaccessibility. Earlier studies have shown that mechanical pretreatment, such as roll milling, of wheat straw can lead to a reduction of the material crystallinity index from 70 to $58 \%$, with a coupled increase of the SSA (0.64 to $1.2 \mathrm{~m}^{2} / \mathrm{g}$, respectively) and an enhanced hydrolysis yield after $8 \mathrm{~h}$ from 1.0 to $3.3 \%$ [48]. To determine whether the increased SSA derived 


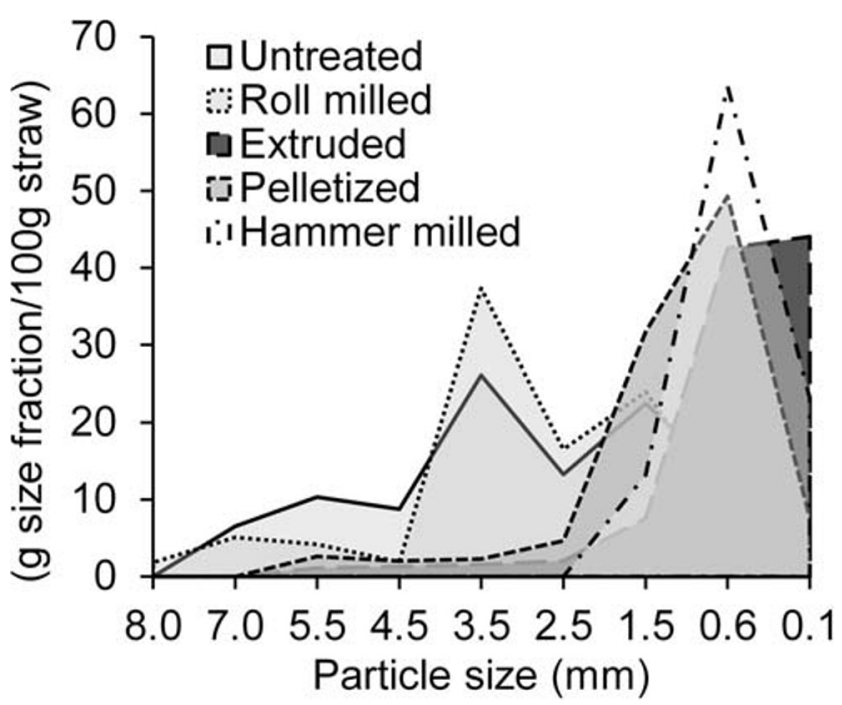

Fig. 4 The particle size distribution of the mechanically pretreated wheat straw, as the weight of each size fraction divided by the total mass

from crystalline cellulose transforming to amorphous cellulose or from changes in the straw particle size would however require additional analysis.

\section{The Effect of Particle Size Reduction on Anaerobic and Enzymatic Degradation}

The most apparent effect of all mechanical pretreatments was the achieved biomass size reduction, see Fig. 4 . The untreated straw had a broader size distribution than any of the other mechanically pretreated straw samples. Roll milling of the straw mostly resulted in the reduction of particles larger than $4.5 \mathrm{~mm}$ and an increase of the particle size fraction around $3.5 \mathrm{~mm}$. In agreement with previous studies, dry extrusion, pelletizing, and knife milling produced straw particles of $\leq$ $2.5 \mathrm{~mm}$ [11], where extrusion and pelletizing had broader distributions than the knife-milled straw. This was expected since the knife mill was equipped with a 1-mm screen, the size of which determines the final particle size. To investigate the impact of particle size on the $\mathrm{AD}$ and the $\mathrm{EH}$ processes, further experiments were therefore performed on roll-milled size fraction wheat straw. The roll-milled straw was used as it had one of the broader particle size distributions but did not contain straw particles too large to handle.

Figure 5 shows how the particle size of the roll-milled wheat straw relates to the BMP, the DMPmax, as well at the EH yield. The roll-milled size fractioned wheat straw generated BMP values that did not seem to depend greatly on the particle size, agreeing with results achieved by Dumas et al. [13]. The maximum daily methane production increased markedly at particle sizes lower than $3 \mathrm{~mm}$, but for larger particles, the trend seemed to cease. The same phenomena was observed for the EH yield after hydrolysis. This observation agrees with previous studies on wheat straw where a particle size of 707-1000 $\mu \mathrm{m}, 250-500 \mu \mathrm{m}$,
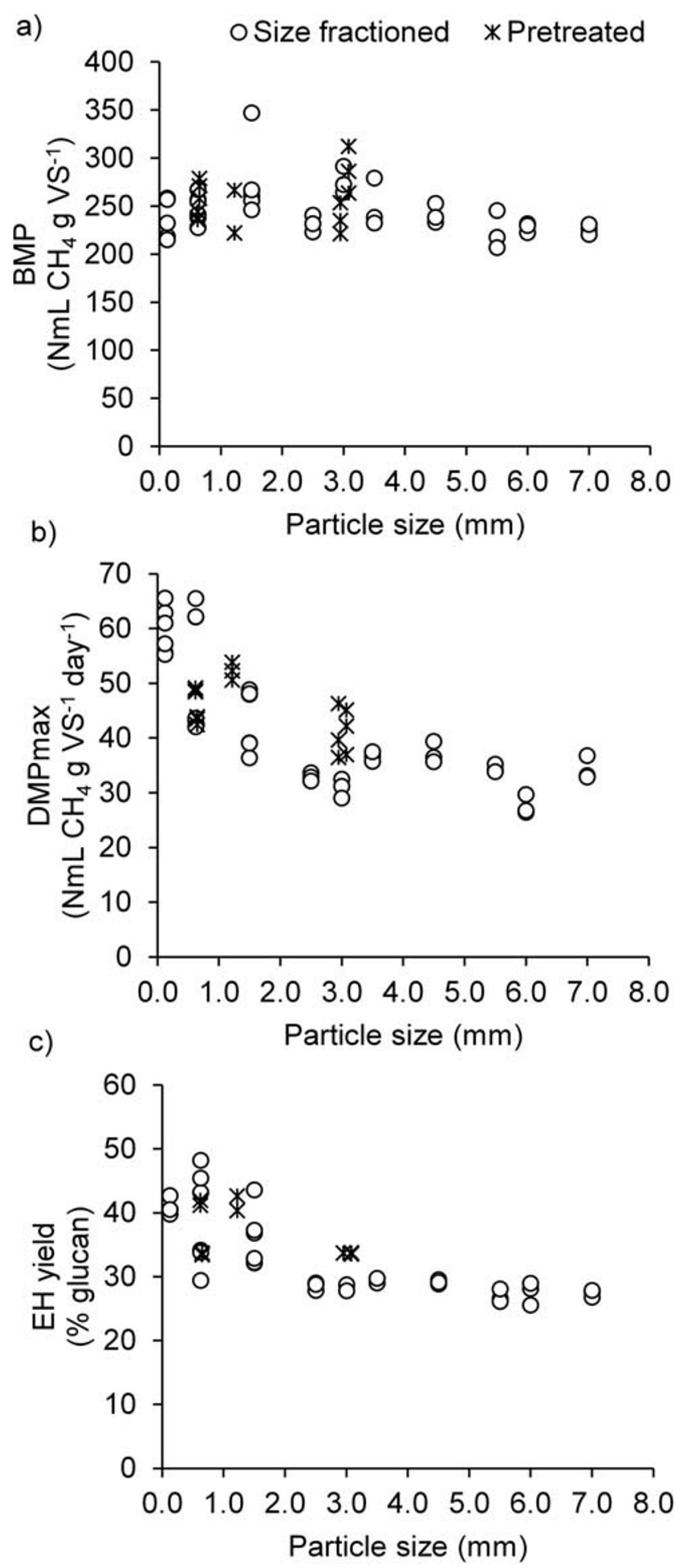

Fig. 5 The roll-milled size fractioned wheat straw (o) as well as the mechanically pretreated wheat straw (x) (i.e., the roll-milled, extruded, pelletized, and hammer-milled straw) showing a the biochemical methane production (BMP) after 35 days of digestion, $\mathbf{b}$ the maximum daily methane production (DMPmax), and $\mathbf{c}$ the enzymatic hydrolysis yield (EH yield) generated after $24 \mathrm{~h}$ of hydrolysis. Each data point represents one analyzed sample 


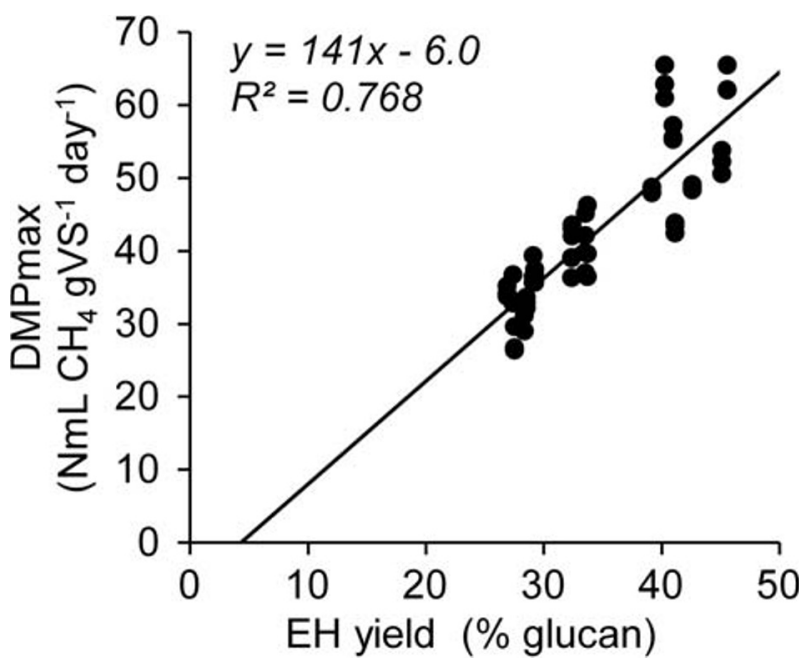

Fig. 6 The maximum daily methane production (DMPmax) obtained from the BMP tests versus the average glucose yield obtained from the enzymatic hydrolysis tests. Linear regression with the least sum of squares method was used. The model was assessed with an $F$ test and showed that $\mathrm{F}<<$ Fcrit, at a 95\% confidence level, confirming the adequacy of the model

and 53-149 $\mu \mathrm{m}$ resulted in a EH yield of 123,153 , and $252 \mathrm{~g}$ glucose/kg DM, respectively [49]. Other studies have also confirmed this relationship, although Silva et al. [50] noted that the particle size of wheat straw had bigger effect on the initial glucose release than on the final yield.

\section{Linear Correlation Between the DMPmax and the EH Yield}

A linear correlation was found between the DMPmax and the EH yield $\left(R^{2}=0.768\right)$, which is shown in Fig. 6 . The particle size did not affect the final methane yield, and therefore a model to predict its final value was not possible for either roll-milled size fractioned or mechanically pretreated wheat straw as no correlation was found between the BMP and the EH yield $\left(R^{2}=0.009\right)$. The lack of fit test showed that no significant difference could be found between the predicted and observed DMPmax values $(p=0.999)$.

The results suggest that it is possible to predict the maximum daily methane production by enzymatic hydrolysis, with a standard error of regression of $\pm 5 \mathrm{NmL} \mathrm{CH}_{4} \mathrm{gVS}^{-1}$ day ${ }^{-1}$ which is very low knowing that the accuracy of the methane flow measurements lies within the same range. Interestingly, linear regression analysis of only size fractioned wheat straw $\left(R^{2}=0.900\right)$ and linear regression of only pretreated wheat straw $\left(R^{2}=0.625\right)$ reinforces the theory that there are most probably physiochemical properties apart from particle size that are altered during mechanical pretreatment and that affect the DMPmax and the EH yield in different ways, giving rise to the lower $R^{2}$ value. It can be expected that the method should be applicable to other types of crops' residues that are rich in carbohydrates and do not contain too much proteins or fats. As the enzymes used in this study only hydrolyzes holocellulose, the anaerobic digestion has to be limited by the accessibility to those carbohydrates. Furthermore, it is possible that also physiochemical properties that affect the DMPmax and the EH yield differently are more present in other crops than wheat straw, which on the other hand opens up for the possibility to identify and to study their impact.

\section{Conclusions}

The purpose of this study was to investigate and characterize mechanically pretreated wheat straw for biogas production, which has led to the following conclusions:

A linear relationship exists between the maximum daily methane production and the $\mathrm{EH}$ yield $\left(R^{2}=0.768\right)$, for mechanically pretreated wheat straw, which shows that enzymatic hydrolysis can replace BMP tests for prediction of the methane production rate. It is however not sufficient for estimating the methane yield, which would require additional characterization.

The particle size of wheat straw, fractioned via sieving, does not affect the biochemical methane potential but rather the maximum daily methane production at particle sizes lower than $3 \mathrm{~mm}$. A particle size reduction from 3 to $0.125 \mathrm{~mm}$ increased the maximum daily methane production with $80 \%$.

Size reduction and changes in the specific surface area does not solely explain the effect mechanical pretreatment has on the digestibility of lignocellulosic biomass.

Funding information Open access funding provided by Lund University. This study was economically supported by the Danish Energy Agency under the program EUDP (Energy Technology Development and Demonstration Program). The sponsors were not involved in the design and execution of the study. The authors are grateful to TK Energi for providing material and roll milling of it, to the Swedish University of Agricultural Sciences for lending out their extruder, to VA Syd for providing inoculum for the BMP tests, and Herje Schagerlöf for the support with BET analysis.

Open Access This article is licensed under a Creative Commons Attribution 4.0 International License, which permits use, sharing, adaptation, distribution and reproduction in any medium or format, as long as you give appropriate credit to the original author(s) and the source, provide a link to the Creative Commons licence, and indicate if changes were made. The images or other third party material in this article are included in the article's Creative Commons licence, unless indicated otherwise in a credit line to the material. If material is not included in the article's Creative Commons licence and your intended use is not permitted by statutory regulation or exceeds the permitted use, you will need to obtain permission directly from the copyright holder. To view a copy of this licence, visit http://creativecommons.org/licenses/by/4.0/.

\section{References}

1. E. Union (2009) Decision no 406/2009/EC of the European Parliament and of the council of 23 April 2009 on the effort of member states to reduce their greenhouse gas emissions to meet 
the community's greenhouse gas emission reduction commitments up to 2020. Official Journal of the European Union. pp 136-148

2. McIntosh S, Vancov T (2011) Optimisation of dilute alkaline pretreatment for enzymatic saccharification of wheat straw. Biomass Bioenergy 35:3094-3103. https://doi.org/10.1016/j.biombioe.2011.04.018

3. Liu X, Zicari SM, Liu G, Li Y, Zhang R (2015) Pretreatment of wheat straw with potassium hydroxide for increasing enzymatic and microbial degradability. Bioresour Technol 185:150-157. https://doi.org/10.1016/j.biortech.2015.02.047

4. Tarasov D, Leitch M, Fatehi P (2018) Lignin-carbohydrate complexes: properties, applications, analyses, and methods of extraction: a review. Biotechnol Biofuels 11:1-28. https://doi.org/10. 1186/s13068-018-1262-1

5. Hendriks A, Zeeman G (2009) Pretreatments to enhance the digestibility of lignocellulosic biomass. Bioresour Technol 100:10-18. https://doi.org/10.1016/j.biortech.2008.05.027

6. Walker L, Wilson D (1991) Enzymatic hydrolysis of cellulose: an overview. Bioresour Technol 36:3-14. https://doi.org/10.1016/ 0960-8524(91)90095-2

7. Mönch-Tegeder M, Lemmer A, Oechsner H, Jungbluth T (2013) Investigation of the methane potential of horse manure. Agric Eng Int CIGR J 15:161-172

8. Finck JD, Goma G (1984) Natural floatation during anaerobic digestion of high strength wastes. Biomass 6:223-234. https://doi. org/10.1016/0144-4565(85)90042-3

9. Tian L, Zou D, Yuan H, Wangb L, Zhang X, Li X (2015) Identifying proper agitation interval to prevent floating layers formation of corn stover and improve biogas production in anaerobic digestion. Bioresour Technol 186:1-7. https://doi.org/10.1016/j. biortech.2015.03.018

10. Menardo S, Airoldi G, Balsari P (2012) The effect of particle size and thermal pre-treatment on the methane yield of four agricultural by-products. Bioresour Technol 104:708-714. https://doi.org/10. 1016/j.biortech.2011.10.061

11. Chen X, Zhang Y, Gu Y, Liu Z, Shen Z, Chu H, Zhou X (2014) Enhancing methane production from rice straw by extrusion pretreatment. Appl Energ 122:34-41. https://doi.org/10.1016/j. apenergy.2014.01.076

12. Sharma SK, Mishra IM, Sharma MP, Saini JS (1988) Effect of particle size on biogas generation from biomass residues. Biomass 17:251-263. https://doi.org/10.1016/0144-4565(88)90107-2

13. Dumas C, Damasceno GSG, Barakat A, Carrère H, Steyer J-P, Rouau X (2015) Effects of grinding processes on anaerobic digestion of wheat straw. Ind Crop Prod 74:450-456. https://doi.org/10. 1016/j.indcrop.2015.03.043

14. Jingura RM, Kamusoko R (2017) Methods for determination of biomethane potential of feedstocks: a review. Biofuel Res J 14: 573-586. https://doi.org/10.18331/BRJ2017.4.2.3

15. Hansen TL, Schmidt JE, Angelidaki I, Marca E, la Cour Jansen J, Mosbæk H, Christensen TH (2004) Method for determination of methane potentials of solid organic waste. Waste Manag 24:393400. https://doi.org/10.1016/j.wasman.2003.09.009

16. Angelidaki I, Alves M, Bolzonella D, Borzacconi L, Campos JL, Guwy AJ, Kalyuzhnyi S, Jenicek P, van Lier J (2009) Defining the biomethane potential (BMP) of solid organic wastes and energy crops: a proposed protocol for batch assays. Water Sci Technol 59:927-934. https://doi.org/10.2166/wst.2009.040

17. Kleinheinz G, Hernandez J (2016) Comparison of two laboratory methods for the determination of biomethane potential of organic feedstocks. J Microbiol Methods 130:54-60. https://doi.org/10. 1016/j.mimet.2016.08.025

18. Wang B, Strömberg S, Nges IA, Nistor M, Liu J (2016) Impacts of inoculum pre-treatments on enzyme activity and biochemical methane potential. J Biosci Bioeng 121:557-560. https://doi.org/10. 1016/j.jbiosc.2015.10.004
19. Thomsen ST, Spliid H, Østergård H (2014) Statistical prediction of biomethane potentials based on the composition of lignocellulosic biomass. Bioresour Technol 154:80-86. https://doi.org/10.1016/j. biortech.2013.12.029

20. Tsapekos P, Kougias P, Angelidaki I (2015) Biogas production from ensiled meadow grass; effect of mechanical pretreatments and rapid determination of substrate biodegradability via physicochemical methods. Bioresour Technol 182:329-335. https://doi.org/10. 1016/j.biortech.2015.02.025

21. Liu X, Bayard R, Benbelkacem H, Buffière P, Gourdon R (2015) Evaluation of the correlations between biodegradability of lignocellulosic feestocks in anaerobic digestion process and their biochemical characteristics. Biomass Bioenergy 81:534-543. https://doi. org/10.1016/j.biombioe.2015.06.021

22. Liew LN, Shi J, Li Y (2012) Methane production from solid-state anaerobic digestion. Biomass Bioenergy 46:125-132. https://doi org/10.1016/j.biombioe.2012.09.014

23. Frydendal-Nielsen S, Jørgensen U, Hjorth M, Felby C, Gislum R (2017) Comparing methods for measuring the digestibility of miscanthus in bioethanol or biogas processing. GCB Bioenergy 9: 168-175. https://doi.org/10.1111/gcbb.12377

24. Wahid R, Hjorth M, Kristensen S, Møller HB (2015) Extrusion as pretreatment for boosting methane production: effect of screw configurations. Energy Fuel 29:4030-4037. https://doi.org/10.1021/ acs.energyfuels.5b00191

25. Hansen KS, Rav C, Nielsen EK, Koch T, Porte C, Christiansen P, Rasmussen AA, Bay N (2017) Pre-treatment of biomass by rolling a combined experimental and numerical analysis. Proceedings of 25th European biomass conference and exhibition, Stockholm. https://doi.org/10.5071/25thEUBCE2017-2CO.13.1

26. Resh MG, Baker JO, Decker SR (2015) Low solids enzymatic saccharification of lignocellulosic biomass. Laboratory Analytical Procedure, NREL/TP-5100-63351

27. Sluiter A, Hames B, Hyman D, Payne C, Ruiz R, Scarlata C, Sluiter J, Templeton D, Wolfe J (2008) Determination of total solids in biomass and total dissolved solids in liquid process samples. Laboratory Analytical Procedure, NREL/TP-510-42621

28. Sluiter A, Hames B, Ruiz R, Scarlata C, Sluiter J, Templeton D (2008) Determination of ash in biomass. Laboratory Analytical Procedure, NREL/TP-510-42622

29. Sluiter A, Ruiz R, Scarlata C, Sluiter J, Templeton D (2008) Determination of extractives in biomass. Laboratory Analytical Procedure, NREL/TP-510-42619

30. Sluiter A, Hames B, Ruiz R, Scarlata C, Sluiter J, Templeton D, Crocker D (2008) Determination of structural carbohydrates and lignin in biomass. Laboratory Analytical Procedure, NREL/TP510-42618

31. Rothenberg SJ, Flynn DK, Eidson AF, Mewhinney JA, Newton GJ (1987) Determination of specific surface area by krypton adsorption, comparison of three different methods of determining surface area, and evaluation of different specific surface area standards. J Colloid Interf Sci 116:541-554. https://doi.org/10.1016/00219797(87)90150-0

32. Brunauer S, Emmett P, Teller E (1938) Adsorption of gases in multimolecular layers. J Am Chem Soc 60:309-319. https://doi. org/10.1021/ja01269a023

33. Tufail T, Saeed F, Imran M, Umair Arshad M, Muhammad Anjum F, Afzaal M, Bader Ul Ain H, Shahbaz M, Aslam Gondal T, Hussain S (2018) Biochemical characterization of wheat straw cell wall with special reference to bioactive profile. Int J Food Prop 21: 1303-1310. https://doi.org/10.1080/10942912.2018.1484759

34. Buswell A, Hatfield W (1936) Bulletin No. 32, Anaerobic fermentations, State of Illinois, Urbana, Illinois

35. Angelidaki I, Sanders W (2004) Assessment of the anaerobic biodegradability of macropollutants. Rev Environ Sci Bio 3:117-129. https://doi.org/10.1007/s11157-004-2502-3 
36. Sattler W, Esterbauer H, Glatter O, Steiner W (1989) The effect of enzyme concentration on the rate of the hydrolysis of cellulose. Biotechnol Bioeng 33:1221-1234. https://doi.org/10.1002/bit. 260331002

37. Hjorth M, Gränitz K, Adamsen AP, Møller HB (2011) Extrusion as a pretreatment to increase biogas production. Bioresour Technol 102:4989-4994

38. Pérez-Rodríguez N, García-Bernet D, Domínguez JM (2017) Extrusion and enzymatic hydrolysis as pretreatments on corn cob for biogas production. Renew Energ 107:597-603. https://doi.org/ 10.1016/j.renene.2017.02.030

39. Galbe M, Zacchi G (2007) Pretreatment of Lignocellulosic materials for efficient bioethanol production. Adv Biochem Eng 108:4165. https://doi.org/10.1007/10_2007_070

40. Dutta SK, Chakraborty S (2016) Pore-scale dynamics of enzyme adsorption, swelling and reactive dissolution determine sugar yield in hemicellulose hydrolysis for biofuel production. Scientific report 6, Nature. https://doi.org/10.1038/srep38173

41. Hall M, Bansal P, Lee JH, Realff MJ, Bommarius AS (2010) Cellulose crystallinity - a key predictor of the enzymatic hydrolysis rate. FEBS J 277:1571-1582. https://doi.org/10.1111/j.1742-4658. 2010.07585.x

42. Han G, Deng J, Zhang S, Bicho P, Wu Q (2010) Effect of steam explosion treatment on characteristics of wheat straw. Ind Crop Prod 31:28-33. https://doi.org/10.1016/j.indcrop.2009.08.003

43. Chesson A, Gardner PT, Wood TJ (1997) Cell wall posority and available surface area of wheat straw and wheat grain fractions. J Sci Food Agr 75:289-295. https://doi.org/10.1002/(SICI)10970010(199711)75:3<289::AID-JSFA879>3.0.CO;2-R
44. Schülein M (1988) Cellulases of Trichoderma reesei. Method Enzymol 160:234-242. https://doi.org/10.1016/0076-6879(88) 60125-X

45. Cowling EB, Kirk TK (1976) Properties of cellulose and lignocellulosic materials as substrates for enzymatic conversion processes. Biotechnol Bioeng Symp 6:95-123

46. Lamed R, Setter E, Bayer EA (1983) Characterisation of a cellulose-binding, cellulase-containing complex in Clostridium thermocellum. J Bacteriol 156:828-836

47. Marousek J (2013) Prospects in straw disintegration for biogas production. Environ Sci Pollut Res 20:7268-7274. https://doi.org/ 10.1007/s11356-013-1736-4

48. Gharpuray MM, Lee Y-H, Fan LT (1983) Structural modification of lignocellulosics by pretreatment to enhance enzymatic hydrolysis. Biotechnol Bioeng 15:157-172. https://doi.org/10.1002/bit. 260250113

49. Pedersen M, Meyer AS (2009) Influence of substrate particle size and wet oxidation on physical surface structures and enzymatic hydrolysis of wheat straw. Biotechnol Prog 25:399-408. https:// doi.org/10.1002/btpr.141

50. Silva GGD, Couturier M, Berrin J-G, Buléon A, Rouau X (2012) Effects of grinding processes on enzymatic degradation of wheat straw. Bioresour Technol 103:192-200. https://doi.org/10.1016/j. biortech.2011.09.073

Publisher's Note Springer Nature remains neutral with regard to jurisdictional claims in published maps and institutional affiliations. 